\title{
Farming with rocks and minerals: challenges and opportunities
}

\author{
PETER VAN STRAATEN \\ Department of Land Resource Science, University of Guelph, Guelph, ON, Canada N1G 2W1 \\ Manuscript received on September 29, 2005; accepted for publication on March 13, 2006; \\ presented by OTHON H. LEONARDOS
}

\begin{abstract}
In many parts of the world food security is at risk. One of the biophysical root causes of falling per-capita food production is the declining quality and quantity of soils. To reverse this trend and increase soil fertility soil and plant nutrients have to be replenished. This review provides a literature survey of experiences of using multi-nutrient rock fertilizers for soil fertility enhancement from temperate and tropical environments. Advantages and limitations of the application of rock fertilizers are discussed. Examples are provided from two successful nutrient replenishment projects in Africa where locally available rock fertilizers are used on highly leached acid soils. The potential of combining organic materials alongside rock fertilizers in soil fertility replenishment strategies is stressed.
\end{abstract}

Key words: soil nutrient replenishment, rock fertilizer, phosphate rock.

\section{INTRODUCTION}

Food is essential for life. But despite major efforts to alleviate food shortage and outright hunger of millions of people, there are still approximately 800 million individuals who go to bed with empty stomachs every night. The need to feed approximately 9 to 10 billion people during the middle of the $21^{\text {st }}$ century will put increasing pressure on land resources and it is obvious that the production of food will have to rise to keep pace with rising food demands. The per capita food production is still declining in some parts of the world, for example in Sub-Saharan Africa.

One of the biophysical root causes of falling per capita food production is the declining quality and quantity of the land resource base, in particular the soil (Sanchez et al. 1997, Sanchez 2002). Soils, the foundation for survival and food security,

E-mail: pvanstra@uoguelph.ca are increasingly over-exploited in some parts of the world. In order to reverse this trend of land and soil degradation it is necessary to either expand the land base under cultivation or to intensify crop production per unit of land. But even if the land base is extended, most of the additional land that would be brought into cultivation is of lower quality and at risk for soil degradation. Clearly, the declining soil quantity and quality in large parts of the developing world poses a threat to food security.

Some land has inherently low fertility because of the soils overly 'infertile' rock formations. Other land is made less fertile due to human intervention, such as the extraction of nutrients through harvesting and other 'exports' without replenishing the extracted soil nutrients. In some parts of Africa the soils are degraded, eroded and successively 'mined' of their nutrients (Sanchez et al. 1997, Sanchez 2002). The average annual depletion rate of nutrients is $22 \mathrm{~kg}$ of nitrogen $(\mathrm{N}), 2.5 \mathrm{~kg}$ of phos- 
phorus $(\mathrm{P})$, and $15 \mathrm{~kg}$ of potassium $(\mathrm{K})$ per hectare of cultivated land over the last 30 years in 37 African countries (Stoorvogel et al. 1993, Smaling et al. 1997). This corresponds to an annual loss equivalent to US\$ 4 billion in fertilizers (Sanchez 2002). Both, the inherent and human induced infertile and degraded soils are biophysical causes for poor crops, for poor human nutrition and consequently for poverty. The restoration of soil fertility through nutrient replenishment should be one of the agricultural entry points to raise production of food crops. However, short-term 'quick-fix' agrochemical input strategies are not needed, but rather long-term support for more regenerative, ecologically sustainable land management practices.

The 'green revolution' in Asia provided impressive steps forward with regards to food production, but in recent years the rate of increase has slowed down considerably. And the green revolution was based largely on genetic improvements of crop varieties (notably rice), supported by applications of agrochemical inputs such as fertilizers, pesticides and herbicides as well as improved irrigation techniques (Conway 1997). It is important to note that the external inputs for higher crop production, such as fertilizers, pesticides and herbicides, are reliant on non-renewable fossil fuels. With increasing costs for transport and natural gas and oil, the use of these agrochemical inputs becomes more and more expensive, especially for resourcepoor, small-scale farmers. Their energy-intensive production and shipment around the world is, in the long run, not sustainable. In addition, many of the high external input practices in the green revolution have been environmentally not very sound, and are in fact far from 'green' (Conway 1997).

We require practical, low-cost and resultoriented long-term strategies that address the needs of farmers and the need for better and long-term care of the land. In order to move towards longer-term and more practical land and soil restoration, farmers, researchers and extensionists have to look for alternative solutions. Ideally, their combined action will contribute to a more long-term approach to en- hance the quality of soils, land and ecosystems, and ultimately the lives of people.

There are several ways to enhance and maintain the health of the soil basis. The application of so-called agrogeological practices is only one of the biophysical instruments that are used to tackle long-term soils related problems. Agrogeology, or the use of 'rocks for crops' (van Straaten 2002), is an interdisciplinary approach that aims to study geological processes and natural rock and mineral materials that contribute to the maintenance of agroecosystems (van Straaten and Fernandes 1995, van Straaten 2002). It is an applied, problem-solving, interdisciplinary earth and agricultural science that has a specific role in integrated nutrient management strategies.

There are two aspects of agrogeology: the role of parent material on soil development and soil productivity, and the beneficial application of geological materials to enhance the productivity of agricultural crops and contribute to better management of horticultural and forestry systems (see book 'Rocks for Crops', van Straaten 2002). It must be emphasized that an agrogeological intervention is a small, albeit important resource-based intervention among many others that contribute to more regenerative and more sustainable land management. These interventions have to be part of an overall strategy to enhance sustainable soil use, enhance sustainable land use, and ultimately, enhance sustainable livelihoods.

This paper highlights a number of experiences using rocks and minerals in soil management as well as some of the advantages of using rocks and minerals over soluble fertilizers, and a few of the limitations of using these geological resources in agriculture.

\section{LOW-COST, LOCALLY AVAILABLE FERTILIZERS}

Nutrients are essential for plant growth. From the 18 elements essential for higher plants (Brady and Weil 1999), all of them, with the exception of nitrogen, are derived from naturally occurring rocks 
and minerals. The fertilizer industry extracts and processes naturally occurring rocks and minerals to produce soluble fertilizers, with the exception of nitrogen fertilizers. However, the fertilizer industry focuses almost exclusively on the production of fertilizers containing the three macronutrients, nitrogen $(\mathrm{N})$, phosphorus $(\mathrm{P})$ and potassium $(\mathrm{K})$, and not on secondary nutrients and micronutrients.

Most commercial farming practices in the world rely on either organic or agrochemical or mixed organic/inorganic nutrient inputs to increase crop production. Currently, these synthetically produced highly concentrated, soluble fertilizers are shipped over long distances at high costs. A tonne of fertilizer may cost US\$ 90 at the site of production. At a harbour in Africa, a long distance away, the price for the same tonne of fertilizer has increased substantially, and transport to inland countries will increase the price again. When these same tonne of fertilizer arrives in a landlocked country, like Uganda, it costs the farmer US\$ 500 per metric tonne (Sanchez 2002). While plantations can afford this price, it is unaffordable to most small-scale farmers.

In addition, the commercially available synthetic fertilizers are frequently not suitable for tropical soils and are in many instances rather inefficient. Baligar et al. (2001) calculated the fertilizer use efficiency in the year of application to be approximately $50 \%$ for $\mathrm{N}, 10-15 \%$ for $\mathrm{P}$, and $40 \%$ for $\mathrm{K}$ from commercial fertilizers. Cognizant of this situation, the fertilizer industry makes efforts to make fertilizers less soluble and more plant efficient. These technological (mainly chemical) efforts are made in order to enhance fertilizer use efficiencies and to reduce losses to the environment. The trend is away from 'fast-release' to 'slower-release' fertilizers, such as the production of highly priced slow release fertilizers, including sulphur-coated urea and polymer coated $\mathrm{N}$ fertilizer (Oertli 1980).

As mentioned before, commercial fertilizers usually provide simply the three macronutrients, N, $\mathrm{P}$ and $\mathrm{K}$. Only in recent years do the fertilizer pro- ducers in some developing countries include essential micronutrients, such as $\mathrm{Zn}$, in their formulas.

In contrast to the technical efforts of the fertilizer industry, the agrogeological approach aims at increasing the nutrient release rates from widely occurring nutrient rich minerals and rocks. As the solubility and release rates of these naturally occurring rocks and minerals are generally very low, the intent is to accelerate the speed of nutrient release through various chemical, physical and biological modification processes. Many of the rock and mineral fertilizer materials contain a multitude of nutrients, including micronutrients (Leonardos et al. 1987).

\section{PRELIMINARY CLASSIFICATION OF LOW-COST, LOCALLY AVAILABLE ROCK AND MINERAL FERTILIZERS}

What are fertilizers and what are rock fertilizers? According to Cooke (1982), a fertilizer is 'any substance that is added to soil to supply one or more plant nutrients and intended to increase plant growth'. According to Finck (1982) 'fertilizers are substances intended to be supplied directly or indirectly to crops in order to promote their growth, increase their yields, or improve their quality'.

'Natural fertilizers are formed in nature and are used in the form in which they occur, without, or with little processing' (Finck 1982). Among the natural fertilizers are organic fertilizers such as poultry and cattle manures, green manures, leaf litter, but also sludges, ashes, and geological resources such as marl and phosphate rock (PR). Fertilizers in the stricter sense, and regulated by national fertilizer laws, are soluble fertilizers with guaranteed total nutrient concentrations and, often more important for the conventional fertilizer user, with guaranteed concentrations of active components.

A preliminary classification of rock and mineral based natural fertilizers is presented below. The range of these naturally occurring rock and mineral based resources spans from multi-nutrient silicate rock fertilizers to by-products from rock 
and coal processing. The focus of agrogeological research and development is the use of these rockand mineral-based natural fertilizers to enhance the soil fertility on smallholder farms.

Natural mineral and rock-based fertilizers can be subdivided into:

- Multi-Nutrient Silicate Rock Fertilizers, e.g. fine grained volcanic rocks,

- Single-Nutrient Rock Fertilizers, e.g. phosphate rock fertilizers,

- Rock Fertilizers from rock and mineral 'waste'

- unprocessed mine 'waste'

- processed rock and coal waste' (e.g. fly ash).

- Translocated Rock Fertilizers:

- alluvial Rock Fertilizer (e.g. nutrient rich river and reservoir sediments)

- airborne Rock Fertilizers (e.g. nutrientrich 'loess' and volcanic ash)

- Specific Nutrient Rock Fertilizers concomitantly applied with organic residues, or biologically modified e.g. by micro-organisms,

- Biofertilizers, organic forms of nutrients extracted from rocks, e.g. organic matter, phytoextracted from phosphate rock.

In the following, only some of the many available geological nutrient resources will be discussed, especially their application in temperate as well as tropical and sub-tropical environments.

\section{MULTI-NUTRIENT SILICATE ROCK FERTILIZERS}

The use of multi-nutrient silicate rock fertilizers as low-cost, locally available geological nutrient sources for agricultural development is not new. Agricultural research with finely ground rocks and minerals, based on the concept of 'bread from stones', started in the 19th century by Missoux (1853/54), Hensel $(1890,1894)$ and others. It was followed many decades later by conceptual and practical work on natural rocks for agricultural development by Keller (1948), Keller et al. (1963). In the last three decades research on rock fertilizers was carried out by Fyfe and co-workers (Fyfe 1981, 1987, 1989, 2000, Fyfe et al. 1983, Leonardos et al. 1987, 2000), Chesworth and van Straaten and co-workers (Chesworth 1982, 1987, 1993, Chesworth et al. 1983, 1985, van Straaten 1987, van Straaten and Chesworth 1985, van Straaten and Pride 1993, van Straaten and Fernandes 1995, van Straaten 2002), by scientists from the British Geological Survey (Appleton 1990, 1994, Mathers 1994), as well as Gillman (1980), Barak et al. (1983), Weerasuriya et al. (1993), Coroneos et al. (1996), Hinsinger et al. (1996), Harley and Gilkes (2000), Gillman et al. (2000, 2002).

The use of whole rock silicate fertilizers is attractive as these types of fertilizers have the potential to supply soils with a large array of macro and micronutrients in comparison to commercially available soluble fertilizers, which commonly only supply the main macronutrients $\mathrm{N}, \mathrm{P}$ and $\mathrm{K}$, but not nutrients such as $\mathrm{Ca}, \mathrm{Mg}$ and micronutrients (Fyfe et al. 1983, Leonardos et al. 1987). Ground silicate rocks should also be considered as slow release fertilizer in situations where leaching rates of conventional fertilizers are particularly high, e.g. in sandy soils under wet climatic regimes (Harley and Gilkes 2000).

The study of silicate rock fertilizers has received renewed interest in recent years due to advances in the understanding of weathering processes, nutrient cycling and biochemical processes at root surfaces. Most fundamental research on nutrient release from rocks and minerals focuses on dissolution rates, as well as the pathways and processes that minerals undergo in soils. While the mineralogical and geochemical processes involved in the dissolution of various rock-forming minerals have been well studied, pathways and reactions in complex soil systems are not as well understood. They include physical, chemical, mineralogical, and biochemical factors and interactions that control the processes at the interface between the miner- 
als, solutions, air and organisms in the soils. In a comprehensive paper, Harley and Gilkes (2000) reviewed the various factors that influence the release of plant nutrients from silicate rock fertilizers.

In earlier laboratory studies, Blum et al. (1989a, b) showed that under laboratory conditions the release rate of nutrients from most ground silicate rocks was very low and that most ground silicate rocks contain a high proportion of elements that have no importance for plant nutrition. However, these researchers showed that certain smectite-rich volcanic ashes could increase the cation exchange capacity of poor soils, for example of forest soils. Unfortunately, it was also proven that the use of most of the tested rock resources would be too slow to be agronomically effective in conventional agriculture.

Von Fragstein et al. (1988) found that the highest cation release rates were from phonolitic volcanic rocks followed by basaltic rock types. Granite powder released the least amounts of cations regardless of extraction methods. In water extracts, the $\mathrm{pH}$ of all samples was alkaline with ground phonolitic rocks reaching a $\mathrm{pH}>10$, basalts $\mathrm{pH} 8-10$, granites $\mathrm{pH} 7-10$. Apart from being good nutrient sources they are also good 'liming materials'.

Volcanic rocks have been singled out as soil ameliorants for their relatively fast rate of weathering and relatively fast release of their contained macro and micronutrients. Their nutrient release rate is commonly faster than that of silica-rich igneous rocks such as granites. Fyfe et al. (1983) remind us that young volcanic areas with weathered lavas and ashes are commonly very fertile agricultural areas.

The effectiveness of silicate rock fertilizers in agricultural practices has been questioned due to conflicting experimental data, the generally low solubility of silicate rocks and the subsequent low availability of nutrients to plants as well as the practicality of applying large amounts of ground rock to agricultural land (Hinsinger et al. 1996, Bolland and Baker 2000, Harley and Gilkes 2000). In addition, some silicate rock fertilizers are diluted with minerals that have no practical nutrient value, such as quartz, and the amount of these unnecessary components is increasing (Harley and Gilkes 2000, Bolland and Baker 2000).

\section{APPLICATIONS OF ROCK FERTILIZERS IN TEMPERATE ENVIRONMENTS}

Over the last few decades there is a small but consistent use of multi-nutrient silicate rock fertilizers in Central Europe, e.g. Germany, and parts of North America, especially in organic farming practices (von Fragstein et al. 1988, Blum et al. 1989a, b). But apart from organic agricultural operations, silicate rock fertilizers are also tested and applied to reverse the declining soil health in Central Europe's forests affected by pollution, especially acid rain.

The forest decline in Central Europe is frequently associated with declining acid neutralization capacity (ANC) and nutrient imbalances in forest soils (e.g. Hildebrand 1991, Huettl and Zoettl 1993). Ground silicate rocks (mainly of basaltic and phonolitic composition) have been tested as a means to raise the $\mathrm{pH}$ in the affected forest soils and to provide a long-term addition of nutrients (e.g. Ca and K). Hildebrand and Schack-Kirchner (2000) and von Wilpert and Lukes (2003) describe positive liming effects on forest soils with silicate rock fertilizers. While the application of $6 \mathrm{t} / \mathrm{ha}$ of volcanic silicate rock fertilizers provided additional $\mathrm{Ca}$ and $\mathrm{K}$ to long-term tree nutrition in the northern Black Forest of Germany (Hildebrand and SchackKirchner 2000), the application of 10t/ha phonolite rock on K-deficient forest soils of Southwest Germany provided additional $\mathrm{Ca}$ and an increase in the soil $\mathrm{pH}$. However, the high dose of Na-rich phonolite also resulted in high rates of Na release, which could cause increased $\mathrm{Na}$ loading of groundwater and potentially contribute to a loss in structural stability of soils (von Wilpert and Lukes 2003). It was concluded that it is important to select the rock fertilizers carefully to achieve the goals of liming and slow nutrient release in forest soils without 
causing new nutrient imbalances and negative ecological impacts.

In other experiments in temperate climates, Bakken et al. (1997, 2000) studied the fertilizing value of various $\mathrm{K}$-bearing rocks and residues from mine tailings on grasslands in Norway. The results of these trials under field conditions show that several percent of the $\mathrm{K}$ bound in biotite concentrate (from feldspar production in Lillesand, Norway) from nepheline in alkaline complexes and epidote schist was actually plant available. And yet, only $30 \%$ of the $\mathrm{K}$ that was added as ground silicate rocks was taken up by plants, as compared to $70 \%$ from $\mathrm{KCl}$. The weathering rate of the rock and mineral products was regarded as too slow to replenish the native pool of plant-available $\mathrm{K}$ within a three-year period with five harvests. The K held in K-feldspar was almost unavailable to the grass plants.

\section{APPLICATION OF ROCK FERTILIZERS IN TROPICAL ENVIRONMENTS}

The application of rock fertilizers in tropical environments has many advantages. Firstly, the dissolution rate of rocks and minerals and the reaction between mineral surfaces and soil solution is enhanced under high temperatures and moisture regimes. Secondly, the potential of applying ground rocks and minerals to soils is elevated as the soils are characterized by low nutrient contents because of high amounts of weathering and leaching, and thus highly receptive to addition of nutrients.

While in some countries in temperate climates the use of multi-nutrient rock fertilizers is growing, especially in the organic agriculture market, there are only few published results from the application of rock fertilizers in developing tropical countries. Although many tests have been carried out in tropical environments, e.g. in Brazil, only a few trial results with well characterized rock and mineral fertilizers as well as soils in which they were applied have been reported.

Published data indicate that some rock and mineral resources can be used as slow-release nutrient-supplying materials for crops in degraded tropical soils and also for forestry and pastures. Many researchers from tropical countries (d'Hotman de Villiers 1961, Roschnik et al. 1967, Leonardos et al. 1987, 1991, Gillman 1980, Gillman et al. 2000, 2002) report positive results from tests using ferromagnesian rich silicate rock fertilizers, such as basalts or ultrapotassic/potassic lavas and tuffs. The reasons for these positive results on highly weathered, nutrient depleted, acid soils are likely the enhanced dissolution of large volumes of ground silicate rocks nutrient rich minerals and rocks under high temperature and moisture conditions and their liming effects. Fine grained rocks containing high proportions of olivine, pyroxene, amphiboles and Ca-rich plagioclase feldspars as well as low concentrations of free quartz have the highest natural weathering rates (Goldich 1938).

In Mauritius, increased yields of sugar cane are reported from systematic field trials (d'Hotman de Villiers 1961). Here, significant yield increases of sugar cane subsequent to the application of large doses (up to 180 tonnes per hectare) of ground basalt have been reported.

In Zimbabwe, Roschnik et al. (1967) tested finely ground basaltic rocks in strongly weathered Kalahari sands in glasshouse experiments. High application rates (5-40 tonnes per acre) showed exponential growth increase in total yield of two slowgrowing legumes. The yield increase of sunflowers grown on Kalahari soils following treatment with 5-40 tons per acre of finely ground basalt showed a linear response curve (Roschnik et al. 1967).

Leonardos et al. (1987) provided results of increased yields from three greenhouse and field trials from lateritic soils in Brazil with beans (Phaseolus vulgaris) and napier grass (Pennisetum purpureum), as well as for slow-growing trees. In other studies, Leonardos et al. (1991) and Theodoro and Leonardos (2006) report on the high agronomic response of ultrapotassic, $\mathrm{Mg}, \mathrm{Ca}, \mathrm{P}$ and micronutrient rich lavas and tuffs from the Mata da Corda Formation, a formation that stretches over large areas $(250 \mathrm{~km} \times 50 \mathrm{~km})$ in the centre of Brazil, in the 


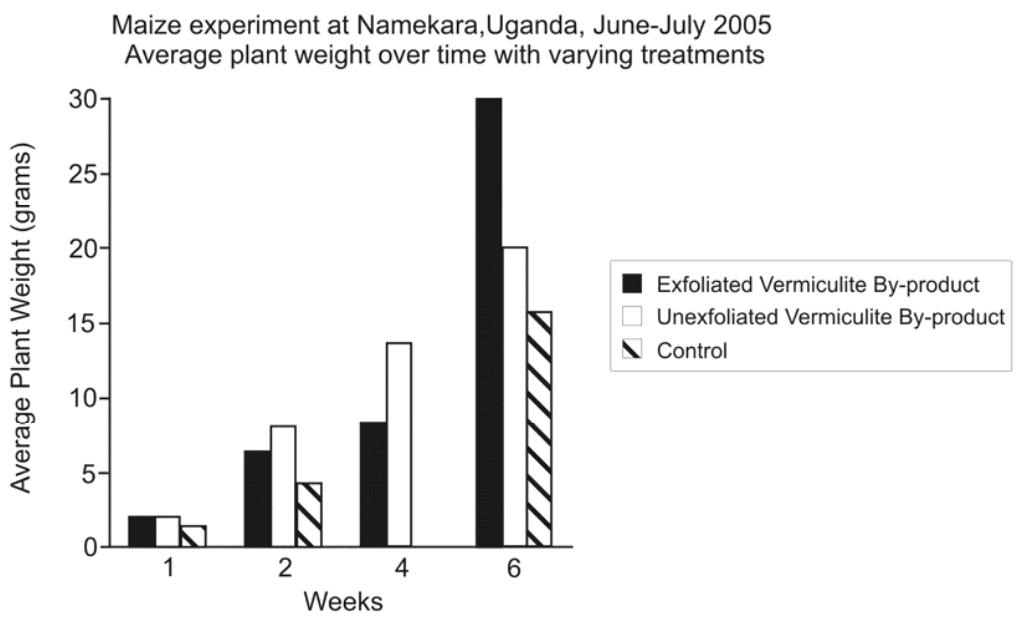

Fig. 1 - Effects of vermiculite by-product on total maize weight (roots and shoots), averaged over three plants, over a six-week period. No control sample was taken in week 4 . Test pots $=26 \mathrm{~L}$ red soils, application rates $180 \mathrm{cc}$ of exfoliated and unexfoliated Namekara vermiculite by-product respectively.

\section{State of Minas Gerais.}

The studies of Gillman (1980) and Gillman et al. $(2000,2002)$ in tropical Australia illustrate the positive effects of the application of large amounts of ground basaltic rocks on weathered and nutrient depleted soils. The application of large quantities of ground basaltic rock raised $\mathrm{pH}$, increased cation exchange capacities, and enhanced cation levels in soils.

In all the examples above, best agronomic performances were achieved with the application of fine grained silica-undersaturated volcanic rocks.

A new example of a potential silicate rock fertilizer is coming from Uganda, where a vermiculitebased rock fertilizer has been developed by Uganda Vermiculite Ltd. Coarse and medium grade vermiculite is extracted from a weathered biotite pyroxenite (Baldock 1969). The vermiculite is extracted and processed before being shipped abroad. The fine fraction of the weathered phosphate containing biotite pyroxenite has been recognized as very valuable 'by-product' for local agronomic applications. The fine fraction 'by-product', only slightly processed through the removal of magnetite and ex- foliation, is currently supplied to local agricultural markets. This vermiculite-based rock fertilizer is still in a product development phase, but as a result of its high initial agronomic performance it is sold as vermiculite based fertilizer to many customers in Uganda. Early seed germination and seed emergence as well as enhanced crop growth of maize, sunflower and cotton show good agronomic performances, probably caused by the release of high concentrations of $\mathrm{Mg}$ and $\mathrm{P}$ from the weathered biotite pyroxenite. Figure 1 illustrates the increased plant mass (roots and shoots) of maize grown in pot experiments in Uganda (P. van Straaten, unpublished data).

The example from Uganda illustrates the opportunity to make use of mafic silicate rock 'wastes', or better, 'by-products' from rock crushing operations and industrial mineral mining operations on their agronomic potential for application in acid nutrient depleted tropical soils.

Another example of the effectiveness of a multi-nutrient silicate rock fertilizer is that of Sri Lanka (Weerasuriya et al. 1993). In this case, however, the silicate rock was not used directly but in 
a modified form. Scrap phlogopite 'waste' from pegmatite mines was ground and acidulated with various acids, including nitric and sulphuric acid. The acidulation process released up to $65 \%$ of $\mathrm{K}$ and $\mathrm{Mg}$, less than $13 \%$ of $\mathrm{Ca}$, and $15-100 \% \mathrm{Mn}$ and $\mathrm{Zn}$. The agronomic evaluation of the application of as little as $200 \mathrm{~kg}$ of acidulated, non-hygroscopic granular phlogopite mica per hectare revealed a yield increase of rice of over $41 \%$ in comparison with recommended application rates of muriate of potash $(\mathrm{KCl})$ and dolomite. The agronomic effectiveness of acidulated feldspars in combination with dolomite was negligible (Weerasuriya et al. 1993).

For increased plant response to rock fertilizer application it is important to characterize and evaluate the mineralogy and chemistry of the selected minerals and match the soil and plant requirements with that of the nutrient supplying capacities of the rock fertilizer. An example of a good match of rock fertilizer with plant requirements for the micronutrient $\mathrm{Fe}$ has been described by Barak et al. (1983). Since peanuts (Arachis hypogaea) often show low yields on calcareous soils due to a lack of iron (Fe-chlorosis) Barak et al. (1983) tested the application of ground $\mathrm{Fe}$-rich basaltic rocks and lapilli tuffs, by-products of local quarrying operations, on calcareous soils. The results show significantly improved iron nutrition, chlorophyll production and growth of peanuts upon application of these Fe-rich volcanic rock fertilizers.

\section{ADVANTAGES AND DISADVANTAGES OF APPLYING MULTI-NUTRIENT SILICATE ROCK FERTILIZERS}

There are several advantages with the application of multi-nutrient silicate rock fertilizers. They include:

- They provide a large number of macro and micronutrients and beneficial elements (e.g. K, $\mathrm{Ca}, \mathrm{Mg}, \mathrm{Cu}, \mathrm{Zn}, \mathrm{Mn}$, and possibly Si (Epstein 1999)).

- They have favourable properties to raise the $\mathrm{pH}$ of soils (liming effect).

- They are suitable as slow-release fertilizers in nutrient depleted acid soils.
- Their application has low environmental impact.

- Many of them are locally available, some of them as quarry 'wastes' and mine 'wastes' from other industrial mineral mining operations.

- They are inexpensive.

Well selected ferromagnesian and silica-undersaturated volcanics and tuffs have shown to be agronomically effective, slow-release fertilizers that can provide many macro and micronutrients to enhance soil fertility and restore soil fertility in the long-term.

As pointed out before, some multi-nutrient silicate rock fertilizers can be found as 'wastes' from quarry operations, or 'wastes' from other industrial mineral mining operations. But the rock fertilizers have to be chosen carefully in order to meet the nutritional requirements of the degraded soils and the crops grown on them.

The use of mafic rock fertilizers as slow-release fertilizers is especially useful in degraded soils where long-term ameliorative effects are needed, e.g. in forest and pasture management systems. Many of these rock fertilizers have good potential in environments where the release of nutrients is enhanced due to high temperature and moisture regimes, e.g. in tropical environments.

Disadvantages of many other rock materials, including silica-rich igneous rocks like granites, contain generally low nutrient concentrations and very low solubility. Both characteristics can negatively affect the agronomic effectiveness of shortterm crops, particularly in temperate climates. Also, silicate-rich rock fertilizers contain large amounts of non-essential elements and minerals, e.g. quartz. In order to be agronomically effective the application rate is commonly in the range of several tonnes per hectare therefore making it costly and labourintensive. In addition, the production of silicate rock fertilizers requires high-energy inputs for crushing and grinding. And their place value is important as shipping large amounts of silicate rock fertilizers over large distances is likely uneconomical and environmentally not sustainable. 


\section{SINGLE-NUTRIENT ROCK FERTILIZERS}

The main nutrient limiting factors in many tropical and sub-tropical environments are $\mathrm{N}$ and $\mathrm{P}$, and in some highly degraded soils also $\mathrm{K}$ and other nutrients. While $\mathrm{N}$ can be provided from the air by biological nitrogen fixation (BNF) and organic sources, $\mathrm{P}$ and $\mathrm{K}$ and all other plant nutrients must be provided from rocks and minerals.

Considerable amount of research has been conducted in the last few decades to find alternative local PR resources to meet the soils requirements for $\mathrm{P}$. There is considerable information on the use of phosphate rock (PR) resources for direct application, and on modification techniques of the various PR resources (for example: Chien and Hammond 1978, McClellan and Notholt 1986, Léon et al. 1986, Chien and Menon 1995b, Van Kauwenbergh 2003). The main research thrust has been on the direct application of finely ground phosphate rocks. The agronomic responses vary strongly from negligible to comparable with TSP. The factors influencing the agronomic effectiveness of PR reach from rock factors, to soil factors to plant and management factors (Chien and Menon 1995a). It is well known that sedimentary francolite-rich PRs are in general more agronomically effective than igneous fluorapatites (Van Kauwenbergh 2003).

Based on years of research and experiences, researchers have developed predictive models indicating the expected agronomic response to certain phosphate rocks on the basis of mineralogical factors as well as soil factors (Chien and Hammond 1978, McClellan and Gremillion 1980, Robinson et al. 1992, Chien and Menon 1995a, Van Kauwenbergh 2003). While many of the positive agronomic results confirmed the prediction from laboratory studies, many negative agronomic results of the direct application of PR can be explained by the choice of unsuitable PR materials or applying the phosphate rocks in unsuitable environments.

The results from South America provide an example for the differing responses based on the difference in the mineralogy and chemistry of the phosphate rocks (Léon et al. 1986). The results of agronomic testing showed that some of the tested phosphate rocks (e.g. from North Carolina, Peru (Bayovar) and Tunisia (Gafsa)) had similar yield responses and agronomic effectiveness to that of chemical triple superphosphates (TSP). All of these very reactive and agronomically effective phosphate rocks are of sedimentary origin. Other phosphates (for example from Brazil, Tapira and Catalao) are igneous phosphate rocks and prove to be largely ineffective when applied directly to soils. Similar geological and mineralogical characterization studies and agronomic experiments have been reported from many places in Sub-Saharan Africa (van Straaten 2002).

In many instances however the reactivity of $\mathrm{PR}$ is too low to release enough $\mathrm{P}$ to the soil and plant roots to be effective in a time frame that matters to the farmers. Also, these PR fertilizers commonly provide only one nutrient, $\mathrm{P}$, to the soils and require other nutrient additions to supply a full range of nutrients to restore soil fertility.

The phosphate rock modification processes that have shown a high potential of enhanced $\mathrm{P}$ nutrient release include:

\section{PHYSICAL MODIFICATION}

Fine grinding (Kühnel and van der Gast 1989, Lim et al. 2003),

Mechanical activation (Gock and Jacob 1984).

\section{PHYSICO-CHEMICAL MODIFICATION}

Fusion and calcination (Cekinski and da Silva 1998).

\section{CHEMICAL MOdification}

\section{Acidulation,}

Partial acidulation (Hammond et al. 1989, Chien and Hammond 1989),

Blending with sulphur (Rajan 1982, 1983, 1987), Heap leaching (Habashi 1989, 1994),

Blending and granulation (Lupin and Le 1983, Chien et al. 1987, Chien and Menon 1995a, van Straaten and Fernandes 1995, Dhliwayo 1999, 
Tagwira 2003),

Ion exchange (Lai and Eberl 1986).

\section{BIOLOGICAL MODIFICATION}

Phospho-composting (Singh and Amberger 1990, 1991, 1998),

Green manuring, for example with Tithonia diversifolia (Sanchez et al. 1997, Palm et al. 1997),

Biosolubilization with microorganisms (see review by Arcand and Schneider 2006)

Use of coir dust (M.L.D. Perera, unpublished data), Mycorrhizal inoculation (Blum et al. 2002, Hagerberg et al. 2003),

Phyto-extraction, (see review by Arcand and Schneider 2006).

In the following, two examples are presented of the successful use of PR on acid P-deficient soils in tropical Sub-Saharan Africa, one in Zimbabwe using a modified 'blended' PR fertilizer with animal manure, and the other, a PR fertilizer in combination with a green manure (van Straaten and Fernandes 1995, Dhliwayo 1999, Tagwira 2003, Smithson et al. 2003, Jama and van Straaten 2006). Both experiences use modified PR sources as supplements to organic amendments and thus provide broad-spectrum nutrient inputs to soils.

\section{EXPERIENCES WITH MODIFIED PR FROM ZIMBABWE}

A relatively new PR modification technique was introduced in Zimbabwe to increase the agronomical effectiveness of a concentrate of the locally available Dorowa PR (DPR) containing 15\% P. DPR has a very low neutral ammonium citrate solubility of $0.8 \%$ (McClellan and Notholt 1986) and is thus not suitable for direct application. The new practice involves the blending and pelletising or compacting of Dorowa phosphate mine 'wastes' (at a rate of 50-90\%) with locally produced TSP (1050\%) (van Straaten and Fernandes 1995, Dhliwayo 1999). Small amounts of this pelletised or compacted DPR/TSP blend is added to animal manure in cattle kraals and later composted in traditional ways.
Both blended materials, pelletised and compacted phosphate blends incorporated and composted in cattle manure showed enhance yield response of maize (Zea mays) on acid soils, but the agronomic response to compacted blends was commonly better than pelletised blends (Dhliwayo 1999), probably due to the more intimate contact between DPR grains and the acidulating TSP. This simple intervention resulted in maize yield increase in farmers' fields by a factor of 2-4 (Dhliwayo 1999, Tagwira 2003).

It is important to point out that the applied combination of modified $\mathrm{P}$ sources and organic farmyard manure provides a broad-based multinutrient input into nutrient deficient acid soils of Central-East Zimbabwe. Not the modified PR source alone but the organic-inorganic blend of PR and manure makes this fertilizer effective and replenishes many nutrients to soil, including $\mathrm{P}$.

\section{EXPERIENCES WITH APPLYING LOCAL PR RESOURCES IN COMBINATION WITH ORGANIC SOURCES IN WESTERN KENYA}

Considerable research and development has been carried out on phosphate application strategies on acid P-deficient soils (Sanchez et al. 1997, Jama and van Straaten 2006). While large amounts of research have been done on direct application of phosphate rock, the emphasis in the project below are on the combined soil fertility restoring effects of mixing organic sources, in this case the $\mathrm{N}$ and K-rich prolific roadside shrub Tithonia diversifolia $(\mathrm{N}=3.6 \%$, $\mathrm{P}=0.3 \%, \mathrm{~K}=4.3 \%$ ) with locally available phosphate rock (Minjingu PR, 13\% P). Field and farm experiments have shown that the combination of locally available organic sources ( $T$. diversifolia) and inorganic locally available reactive PR resources can give similar results to the application of imported fertilizers (e.g. urea and TSP) (Sanchez et al. 1997), see Fig. 2.

The general result of several years of research and development work using integrated nutrient management strategies in Western Kenya is the combination of locally available, locally grown or- 
ganic nutrient sources with inorganic $\mathrm{P}$ sources (see Jama and van Straaten 2006). Both, the local PR and organic resources together provide a 'smorgasbord' of nutrients essential to plant growth and the long-range improvement of soils.

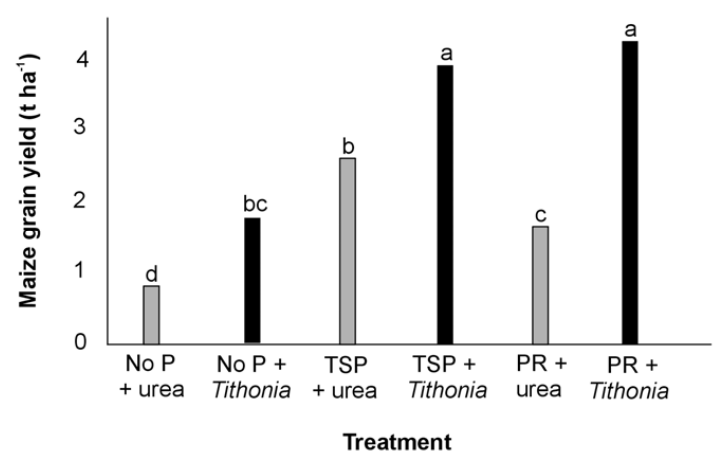

Fig. 2 - Maize grain yield responses to $\mathrm{P}$ and $\mathrm{N}$ applications on an acid soil in western Kenya. $\mathrm{P}$ was provided in the forms of TSP and Minjingu PR at a rate of $250 \mathrm{~kg} \mathrm{P}^{-1}$ respectively, $\mathrm{N}$ was provided as urea and as locally available green foliar biomass of Tithonia diversifolia at a rate of $60 \mathrm{~kg} \mathrm{ha}^{-1}$. Blanket application of $60 \mathrm{~kg} \mathrm{~K} / \mathrm{ha}$ was added to each crop. Means in a column followed by the same letter are not significantly different at the $\mathrm{P}=0.05$ level by the LSD test. Source: Sanchez et al. 1997.

The maize yield of smallholder farmers in Western Kenya before organic/PR intervention was approximately 1 tonne ha ${ }^{-1}$ per family of 6 . After the introduction of an integrated management strategy with organic inputs and $\mathrm{P}$ sources including local phosphate rocks (from Minjingu) the maize yield increased to 2-4 tonnes $\mathrm{ha}^{-1}$ per family of 6 . The practice of using locally available organic sources in combination with P-sources including locally available phosphate rock brought approximately 150.000 families in Western Kenya out of poverty (P.A. Sanchez, pers. comm. 2004).

\section{EXPERIENCES WITH APPLICATION OF K-BEARING ROCK FERTILIZERS}

The release of $\mathrm{K}$ from minerals and rocks has been studied over many decades. The release rate of $\mathrm{K}$ from K-feldspar is extremely slow and the agronomic effectiveness regarded as very low (Sanz
Scovino and Rowell 1988), as is the application of granite fines in a dry area of Western Australia (Bolland and Baker 2000). There are however some $\mathrm{K}$-minerals that are more suitable for chemical and biological weathering and K-release than others, for example leucite and other feldspathoid or Kzeolite bearing volcanic rocks, as well as biotite and phlogopite mica. The release of elements from the two micas phlogopite and biotite is slow, but the release of $\mathrm{K}$ can be accelerated through biologically induced activities.

Berthelin et al. (1991), Hinsinger and Jaillard (1993), and Hinsinger et al. (1993) demonstrated $\mathrm{K}$ release from phlogopite by biologically induced transformations at the rhizosphere. They could measure enhanced weathering and mineral transformation from phlogopite to vermiculite with the release of $\mathrm{K}$ for plant uptake.

Another successful modification technique to enhance the solubility and K-release from phlogopite and biotite (Weerasuriya et al. 1993) is through acidulation with nitric and sulphuric acids (see above).

\section{CHALLENGES TO THE USE OF MULTI-NUTRIENT AND SINGLE-NUTRIENT ROCK AND MINERAL FERTILIZERS}

The agronomic effectiveness of rock fertilizers is a function of rock factors (e.g. mineralogy and chemistry), soil factors (e.g. organic matter content, $\mathrm{pH}$, texture), crop factors, other environmental factors, and management factors.

The main challenge in the use of rock fertilizers is to increase the solubility of rocks and minerals and to enhance nutrient release from both multinutrient silicate rock fertilizers and from single nutrient fertilizers like phosphate rock. This can be done by physically modifying and/or chemically changing the mineral surfaces. Physically changing the surface area of the minerals, e.g. through fine grinding, can enhance the release of nutrients (Lim et al. 2003). Chemically modifying the surfaces, e.g. through acidulation can also enhance the solubility and nutrient release from minerals. The re- 
lease of $\mathrm{K}$ and $\mathrm{Mg}$ from phlogopites through acidulation is an example of how nutrient release can be enhanced (Weerasuriya et al. 1993).

Another challenge is to match the plant and soil requirements to the nutrient supplying capacities of the rock fertilizers. Many failures that occur with the use of multi-nutrient and single-nutrient rock fertilizers are caused by the poor selection of the appropriate rock fertilizer compositions and specific crop requirements, as well as from the poor selection of climatic environments. Mafic rocks, for example, contain large amounts of ferromagnesian minerals with high concentrations of plant nutrients such as $\mathrm{Ca}, \mathrm{Mg}, \mathrm{Fe}$ and trace elements and are thus suitable for many degraded soils. Felsic rocks and mica-bearing rocks, on the other hand, contain less of the above nutrients but more of the plant nutrient $\mathrm{K}$ and are thus more suitable for soils and crops that have higher $\mathrm{K}$ requirements.

However, because of the low solubility of minerals and rocks it is commonly necessary to apply large volumes of rock fertilizers to the soils. While this might be possible where the rock materials are regarded as 'waste' and/or available close to the area where they are needed, it might be uneconomic to extract and transport large volumes of these materials. A way out of this situation is to modify the rock fertilizers in such a way as to increase the release rates and thus reduce the amounts of materials that must be applied to the soils.

Challenges also include the economics of transportation and grinding and other modification techniques of the rock fertilizers.

A lack of collaboration between soil scientists, geoscientists and farmers often causes inappropriate choices of multi- and single-nutrient geological resources for the right soil and crop thus failing in their common goal to enhance soil fertility in a more sustainable manner.

\section{OPPORTUNITIES}

Most of the research with multi-nutrient rock fertilizers has been conducted with direct application of ground silicate rock fertilizers only. In contrast to the many modification techniques used with singlenutrient phosphate rock fertilizers, there are only limited experiences of multi-nutrient silicate rock fertilizer modifications, such as fine milling (J. Priyono, pers. comm. 2005) and acidulation (in the case of mica, Weerasuriya et al. 1993).

Methods of biological modification such as composting, mixing with acidulating sulphur, partial acidulation and heap leaching, as well as blending with acid producing compounds have been successfully tested with PR raw materials and similar modification methods should be also tested with various multi-nutrient rock fertilizers.

Chemical, physical and biological modification processes that can improve the agronomic effectiveness of rock fertilizers have the potential to greatly enhance soil fertility on nutrient deficient acid soils and subsequently food production in developing countries. The combination of ground silicate rock fertilizers and organic residues needs more attention. This will involve studies of inorganicorganic interactions and transformations from mineral to organic compounds. More laboratory studies, greenhouse and field experiments are needed to test rocks and minerals that possess high cation concentrations and relatively high weathering potential, like feldspathoids, as well as mafic, ultrapotassic and olivine-rich volcanic rocks. It is also important to better understand which soils and which plants may promote the dissolution of silicate rock fertilizers. More research and development on microbially induced nutrient release from multi-nutrient bearing rocks and minerals should be carried out to produce biologically enhanced rock fertilizers.

It is important to carry out more collaborative investigations with all stakeholders, including geoscientists, soil scientists, extensionists and farmers, and expand the research and development efforts to a more holistic ecosystem approach. All stakeholders must get a better understanding of ecosystem functions and the agricultural functions within this ecosystem to maintain or enhance the natural en- 
vironment. And, as Sherwood and Uphoff (2000) stated, we have to engage farmers rather than change farmers. We should involve farmers as partners in improving soil health. Soil researchers, geoscientists, extensionists and farmers should solve soil related problems together and develop and spread better practices and methods, including agrogeological ones, to ultimately provide better livelihoods for family farmers.

The selection of rock and mineral materials as silicate rock fertilizers depends largely on the nutrient deficiency and the need to replenish nutrients in the soils. While fine grained mafic silicate rock fertilizers are more suitable to release various nutrients (e.g. $\mathrm{Ca}, \mathrm{Mg}$, micronutrients) they are generally low in $\mathrm{K}$ and therefore less suitable in K-deficient soils.

Obviously, multi-nutrient silicate rock fertilizers and many single nutrient rock fertilizers will not replace conventional fertilizers that react fast in soil solution for easy access to plant roots. However, research has shown the large potential of applying appropriate rock and mineral fertilizers in combination with organic matter to highly weathered and degraded soils in the long-term.

Rock fertilizers represent inexpensive and environmentally sound fertilizer options for farmers in areas of the world with infertile soils and suitable climates. With the right choice of locally available rock materials for the right soils, these materials have shown to be of benefit to local agriculture, especially when modified or blended with locally available organic materials.

\section{RESUMO}

Em muitas partes do mundo a segurança alimentar está em risco. A raiz de uma das causas biofísicas da queda da produção alimentar per capita é o declínio da qualidade e quantidade de solos. Para reverter essa tendência e aumentar a fertilidade, ambos solo e nutrientes para as plantas precisam ser repostos. Este artigo aborda uma pesquisa bibliográfica de experiências na utilização de rochagem com multi-nutrientes para intensificação da fertilização do solo em ambientes temperados e tropicais. As vantagens e as limitações na aplicação de pó de rocha são discutidas. São apresentados dois projetos bem sucedidos de substituição de nutrientes na África, onde as rochas disponíveis no local são utilizados em solos ácidos altamente lixiviados. É enfatizado o potencial da combinação de materiais orgânicos juntamente com pó de rocha nas estratégias de reposição da fertilidade dos solos.

Palavras-chave: reposição de nutrientes do solo, rochagem, rocha fosfática.

\section{REFERENCES}

APPLETON JD. 1990. Rock and mineral fertilizers. Appropriate Technology 17: 25-27.

ApPleton JD. 1994. Direct-application fertilizers and soil amendments - appropriate technology for developing countries? In: MATHERS SJ AND NOTHOLT AJG (Eds), Industrial minerals in developing countries. AGID Report Series Geosciences in International Development 18: 223-256.

ARCAND M AND SCHNEIDER KD. 2006. Plant and microbial based mechanisms to improve the agronomic effectiveness of phosphate rock. A review An Acad Bras Cienc 78: 791-807.

BAKKen AK, GaUtneb H And Myhr K. 1997. The potential of crushed rocks and mine tailings as slowreleasing $\mathrm{K}$ fertilizers assessed by intensive cropping of Italian ryegrass in different soil types. Nutr Cycl Agroecosyst 47: 41-48.

BAKKen AK, Gautneb H, Sveistrup T And MyHr K. 2000. Crushed rocks and mine tailings applied as $\mathrm{K}$ fertilizers on grassland. Nutr Cycl Agroecosyst 56: $53-57$.

BALDOCK JW. 1969. Geochemical dispersion of copper and other elements at the Bukusu carbonatite complex, Uganda. Trans Inst Min Metall (Section B) 78: B12-B28.

BAligar VC, FAgeria NK AND He ZL. 2001. Nutrient use efficiency in plants. Comm Soil Sci Plant Anal 32: 921-950.

BArak P, Chen Y And Singer A. 1983. Ground basalt and tuff as iron fertilizer for calcareous soils. Plant Soil 73: 155-158.

Berthelin J, Leyval C, LAheurte F AND DE GiUDICI P. 1991. Involvement of roots and rhizosphere 
microflora in the chemical weathering of soil minerals. In: ATKINSON D (Ed), Plant root growth - An ecological perspective. British Ecolog Soc Blackwell Scientific, p. 187-200.

Blum JD, Klaue A, Nezat CA, Driscoll CT, Johnson CE, SicCAMA TG, EAgARs C, FAHEY TJ AND LIKENS GE. 2002. Mycorrhizal weathering of apatite as an important calcium source in base-poor forest ecosystems. Nature 417: 729-731.

Blum WeH, Herbinger B, Mentler A, Ottner F, Pollak M, Unger E And Wenzel WW. 1989a. Zur Verwendung von Gesteinsmehlen in der Landwirschaft. I. Chemisch-mineralogische Zusammensetzung und Eignung von Gesteinsmehlen als Duengemittel. Zeitschrift Pflanzenernährung Bodenkunde 152: 421-425.

Blum WeH, Herbinger B, Mentler A, Ottner F, Pollak M, Unger E and Wenzel WW. 1989b. Zur Verwendung von Gesteinsmehlen in der Landwirschaft. II. Wirkung von Gesteinsmehlen als Bodenverbesserungsmittel. Zeitschrift Pflanzenernährung Bodenkunde 152: 427-430.

Bolland MDA AND BAKER MJ. 2000. Powdered granite is not an effective fertilizer for clover and wheat in sandy soils from Western Australia. Nutr Cycl Agroecosyst 56: 59-68.

BRADY NC AND WEIL RR. 1999. The nature and properties of soils. $12^{\text {th }}$ ed., Prentice Hall Upper Saddle River, New Jersey, 881 p.

Cekinski E AND DA Silva G. 1998. Technological characterization of Anitapolis (Brazil) phosphate rock as feedstock for fused magnesium phosphate production. Nutr Cycl Agroecosyst 52: 31-35.

Chesworth W. 1982. Late Cenozoic geology and the second oldest profession. Geoscience Canada 9: 54-61.

CHESWORTH W. 1987. Geology and agriculture. In: WaChIRA JK AND Notholt AJG (Eds), Agrogeology in Africa. Commonw Sci Council, Techn Publ Ser 226: 5-11.

Chesworth W. 1993. The first twenty-nine days: Prospects for agrogeology. In: PRIDE C AND VAN StraAten P (Eds), Agrogeology and small-scale mining. Small Mining International, Bulletin 5-6: $2-3$.
Chesworth W, Magias-Vasquez F, Acquaye D AND Thomson E. 1983. Agricultural alchemy: stones into bread. Episodes 1: 3-7.

Chesworth W, van StraAten P, Semoka J And MCHiniyo E. 1985. Agrogeology in Tanzania. Episodes 8: 257-258.

ChIEn SH AND HAMmond LL. 1978. A comparison of various laboratory methods for predicting the agronomic potential of phosphate rocks for direct application. Soil Sci Soc Am J 42: 935-939.

Chien SH AND Hammond LL. 1989. Agronomic effectiveness of partially acidulated phosphate rock as influenced by soil phosphorus-fixing capacity. Plant Soil 120: 159-164.

Chien SH And Menon RG. 1995a. Factors affecting the agronomic effectiveness of phosphate rock for direct application. Fert Res 41: 227-234.

Chien SH And Menon RG. 1995b. Agronomic evaluation of modified phosphate products. Fert Res 41: 197-209.

Chien SH, Adams F, Khasawneh FE and Henao J. 1987. Effects of combinations of triple superphosphate and a reactive phosphate rock on yield and phosphorus uptake by corn. Soil Sci Soc Am J 51: 1656-1658.

Conway G. 1997. The doubly green revolution: Food for all in the $21^{\text {st }}$ century. Penguin Books, London, UK, 335 p.

CoOKe GW. 1982. Fertilizing for maximum yield, $3^{\text {rd }}$ ed., Granada Publ, London, 465 p.

Coroneos C, Hinsinger P ANd Gilkes RJ. 1996. Granite powder as a source of potassium for plants: a glasshouse bioassay comparing two pasture species. Fert Res 45: 143-152.

DHLIWAYO DD. 1999. Evaluation of agronomic potential and effectiveness of Zimbabwe (Dorowa) phosphate rock-based fertilizer materials. Ph.D. thesis. University of Zimbabwe.

D'Hotman de Villiers O. 1961. Soil rejuvenation with crushed basalt in Mauritius. Int sugar J 63: 363-364.

EPStein E. 1999. Silicon. Annual Rev. Plant Physiol Plant Mol Biol 50: 641-664.

FINCK A. 1982. Fertilizers and fertilization. Verlag Chemie, Weinheim, Germany, 438 p. 
FYFE WS. 1981. The environmental crisis: quantifying geosphere interactions. Science 213: 105-110.

FYFE WS. 1987. Sustainable food production and agrogeology. In: PRIDE C AND VAN STRAATEN P (Eds), Agrogeology and small scale mining. Small Mining International, Bulletin 5-6: 4-5.

FYFE WS. 1989. Soil and global change. Episodes 12: 249-254.

FYFE WS. 2000. The life support system - toward earth sense. In: ERNST WG (Ed), Earth systems: processes and issues. Cambridge University Press, p. 506-515.

FyFe WS, KRONBERG BI, LEONARdos OH AND OLORUFEMI N. 1983. Global tectonics and agriculture: a geochemical perspective. Agr Ecosyst Env 9: 383-399.

GILlmAN GP. 1980. The effect of crushed basalt scoria on the cation exchange properties of a highly weathered soil. Soil Sci Soc Am J 44: 465-468.

Gillman GP, BueKKetT DC AND COVEnTRY RJ. 2000. A laboratory study of application of basalt dust to highly weathered soils: effects ion soil cation chemistry. Austr J Soil Res 39: 799-811.

Gillman GP, BURKeTt DC AND COVEnTRY RJ. 2002. Amending highly weathered soils with finely ground basalt rock. Applied Geochem 17: 987-1001.

Gock E AND JACOB KH. 1984. Conceptions for processing the pyrite-bearing phosphorite of Abu Tartur. Berliner Geowissenschafftliche Abhandlungen 50: 381-397.

GoLDICH SS. 1938. A study in rock weathering. J Geol 46: $17-58$.

HABASHI F. 1989. In-situ and dump leaching technology: application to phosphate rock. Fert Res 18: 275-279.

HABASHI F. 1994. Phosphate fertiliser industry: processing technology. Industrial Min, p. 65-69.

Hagerberg D, Thelin G and Wallander $\mathrm{H}$. 2003. The production of ectomycorrhizal mycelium in forests: Relation between nutrient status and local mineral sources. Plant Soil 252: 279-290.

Hammond LL, CHIEN SH, ROY AH AND MOKWUNYE AU. 1989. Solubility and agronomic effectiveness of partially acidulated phosphate rocks as influenced by their iron and aluminum oxide content. Fert Res 19: 93-98.
HARLEY AD AND GILKES RJ. 2000. Factors influencing the release of plant nutrient elements from silicate rock powders: a geochemical overview. Nutr Cycl Agroecosyst 56: 11-36.

Hensel J. 1890. Das Leben. (in German) Verlag Boericke und Tafel, Leipzig, Germany.

Hensel J. 1894. Bread from stones. TAFEL AJ (Ed), Philadelphia, USA.

Hildebrand EE. 1991. The spatial heterogeneity of chemical properties in acid forest soils and its importance for tree nutrition. Water Air Soil Pollution 54: 183-191.

Hildebrand EE AND SCHACK-KIRCHNER H. 2000. Initial effects of lime and rock powder application on soil solution chemistry in a dystric cambisol results of model experiments. Nutr Cycl Agroecosyst 56: 69-78.

Hinsinger P AND JAILlaRd B. 1993. Root-induced release of interlayer potassium and vermiculization of phlogopite as related to potassium depletion in the rhizosphere of ryegrass. J Soil Sci 44: 525-534.

Hinsinger P, Elsass F, JAILlard B AND RobERT TM. 1993. Root-induced irreversible transformation of a trioctahedral mica in the rhizosphere of rape. $\mathrm{J}$ Soil Sci 44: 535-545.

Hinsinger P, Bolland MDA AND GiLKes RJ. 1996. Silicate rock powder: effect on selected properties of a range of soils from Western Australia and on plant growth as assessed in a glasshouse experiment. Fert Res 45: 69-79.

Huettl RF AND Zoettl HW. 1993. Liming as a mitigation tool in Germany's declining forests - reviewing results from former and recent trials. Water Air Soil Pollution 61: 325-338.

JAMA B AND VAN STRAaten P. 2006. Potential of East African phosphate rock deposits in integrated nutrient management strategies. An Acad Bras Cienc 78: 781-790.

KELLER WD. 1948. Native rocks and minerals as fertilizers. Sci Monthly 66: 122-130.

Keller WD, Balgord WD and Reesman AL. 1963. Dissolved products of artificially pulverized silicate minerals and rocks. J Sediment Petrol 33: 191-204.

KÜHNEL RH AND VAN DER GAST SJ. 1989. Forma- 
tion of clay minerals by mechano-chemical reactions during grinding of basalt under water. Appl Clay Sci 4: 295-305.

LAI TM AND EBERL DD. 1986. Controlled and renewable release of phosphorus in soils from mixture of phosphate rock and NH4-exchanged clinoptilolite. Zeolites 6: 129-132.

LÉON LA, FENSTER WE AND HAMMOND LL. 1986. Agronomic potential of eleven phosphate rocks from Brazil, Colombia, Peru and Venezuela. Soil Sci Soc Am J 50: 798-802.

LeOnARdos OH, Fyfe WS AND KRONBERG BI. 1987. The use of ground rocks in laterite systems: an improvement to the use of conventional soluble fertilizers? Chem Geol 60: 361-370.

LEONARdos OH, Ulbrich MLN AND GASPAR JC. 1991. The Mata da Corda volcanics. In: FIELD Guidebook FifTh International KimberLITE CONFEREnCE (Araxa, Bazil), CPRM Special Publ Brasília, 141 p.

LeOnardos OH, TheOdoro SH ANd Assad ML. 2000. Remineralization for sustainable agriculture: A tropical perspective from a Brazilian viewpoint. Nutr Cycl Agroecosyst 56: 3-9.

Lim HH, GILKES RJ AND MCCORMICK P. 2003. Beneficiation of rock phosphate fertilizers by mechanomilling. Nutr Cycl Agroecosyst 67: 177-186.

LUPIN MS AND LE ND. 1983. Compaction - Alternate approach for granular fertilizer. Techn. Bull. T-25, Intern. Fert Dev Center, Muscle Shoals, Alabama, USA.

MATHERS SJ. 1994. Industrial mineral potential of Uganda. In: MATHERS SJ AND Notholt AJG (Eds), Industrial Minerals in Developing Countries. AGID Geosciences in International Development 18: 144-166.

MCClellan GH and Gremillion RL. 1980. Evaluation of phosphatic raw materials. In: KHASAWNEH FE, SAmple EC AND Kamprath EJ (Eds), The role of phosphorus in agriculture. ASA- CSSA-Soil Sci Soc, Madison, Wisconsin, p. 43-80.

McClellan GH AND Notholt AJG. 1986. Phosphate deposits of tropical Sub-Saharan Africa. In: Mokwunye AU And Vlek PLG (Eds), Management of nitrogen and phosphorus fertilizers in Sub-
Saharan Africa. Martinus Nijhoff Publ, Dordrecht, Netherlands, p. 173-223.

Missoux M. 1853/54. Sur l'emploi de la poudre des roches granitiques comme excitant de la vegetation. Compt Rend Acad Sci (Paris) t 36: p. 1136; t 37 : p. 245.

Oertli JJ. 1980. Controlled release fertilizers. Fert Res 1: 103-123.

PALM CA, Myers RJK AND NANDWA SM. 1997. Combined use of organic and inorganic nutrient sources for soil fertility maintenance and replenishment. In: BURESH RJ, SANCHEZ PA AND CALHOUN F (Eds), Replenishing soil fertility in Africa. SSSA Spec Publ 51: 193-217.

RAJAN SSS. 1982. Influence of phosphate rock reactivity and granule size on the effectiveness of 'biosuper'. Fert Res 3: 3-12.

RAJAN SSS. 1983. Effect of sulphur content of phosphate rock/sulphur granules on the availability of phosphate to plants. Fert Res 4: 287-296.

RAJAN SSS. 1987. Phosphate rock and phosphate rock/ sulphur granules as phosphate fertilizers and their dissolution in soil. Fert Res 11: 43-60.

RobINSON JS, SyeRs JK AND BOLAN NS. 1992. Importance of proton supply and calcium sink size in soils in open leaching and closed incubation systems. J. Soil Sci 43: 447-459.

Roschnik RK, GRANT PM AND NDUKU WK. 1967. The effect of incorporating crushed basalt rock into an infertile acid sand. Rhodesia, Zambia, Malawi J Agric Res 5: 133-138.

SALEPWG AND MoKWUNYE AU. 1993. Use of phosphate rocks in the tropics. Fert Res 35: 33-45.

SANCHEZ PA. 2002. Soil fertility and hunger in Africa. Science 295: 2019-2020.

SAnchez PA, Shepherd KD, Soule MJ, Place FM, Buresh RJ, IZAC AN, MOKWUNye AU, KWEsiga FR, NDIRITU CG AND WoOMER PL. 1997. Soil fertility replenishment in Africa: an investment in natural resource capital. In: BURESH RJ, SAnChez PA AND CALHoun F (Eds), Replenishing soil fertility in Africa. SSSA Spec Publ 51: $1-46$.

SAnz Scovino JI And Rowell DL. 1988. The use of feldspars as potassium fertilizers in the savannah of Colombia. Fert Res 17: 71-83. 
SHERwood S AND UPHOFF N. 2000. Soil health: research, practice and policy for a more regenerative agriculture. Appl Soil Ecol 15: 85-97.

Singh CP AND Amberger A. 1990. Humic substances in straw compost with rock phosphate. Biol Waste 31: 165-174.

Singh CP AND AMBERger A. 1991. Solubilization and availability of phosphorus during decomposition of rock phosphate enriched straw and urine. Biol Agric Hortic 7: 261-269.

Singh CP AND Amberger A. 1998. Organic acids and phosphorus solubilization in straw composted with rock phosphate. Biores Techn 63: 13-16.

SMaling A, NANDwa SM AND JANSSEN BH. 1997. Soil fertility in Africa is at stake. In: BURESH RJ, SAnChEZ PA And CALhoun F (Eds), Replenishing soil fertility in Africa. SSSA Spec Publ 51: 47-61.

Smithson P, Jama B, Delve R, Van Straaten P AND BURESH R. 2003. East African phosphate resources and their agronomic performance. In: RAJAN SSS AND CHIEN SH (Eds), Direct application of phosphate rock and related appropriate technology - latest developments and practical experiences: Proceedings of an international meeting, International Center for Soil Fertility and Agricultural Development (IFDC), Muscle Shoals, Alabama USA, Spec Publ IFDC-SP-37: 123-133.

Stoorvogel JJ, Smaling EMA ANd JANSEN BH. 1993. Calculating soil nutrient balances in Africa at different scales: I. Supra-national scale. Fert Res 35: 227-235.

TAGWIRA F. 2003. Potential of Dorowa phosphate rock as a low cost fertilizer for smallholder farmers in Zimbabwe - a review of research done. In: RAJAN SSS AND CHIEN SH (Eds), Direct application of phosphate rock and related appropriate technology latest developments and practical experiences: Proceedings of an international meeting, International Center for Soil Fertility and Agricultural Development (IFDC), Muscle Shoals, Alabama USA, Spec Publ IFDC-SP 37: 397-406.

TheOdoro SH AND LeOnARdos OH. 2006. The use of rocks to improve family agriculture in Brazil. An Acad Bras Cienc 78: 721-730.

VAN KAUWEnBERGH SJ. 2003. Mineralogy and characterization of phosphate rock for direct application.
In: RAJAN SSS AND CHIEN SH (Eds), Direct application of phosphate rock and related appropriate technology - latest developments and practical experiences: Proceedings of an international meeting, International Center for Soil Fertility and Agricultural Development (IFDC), Muscle Shoals, Alabama USA, Spec Publ IFDC-SP 37: 28-49.

VAN StRaAten P. 1987. Agrogeological resources in eastern and southern Africa. In: WACHIRA JK AND Notholt AJG (Eds), Agrogeology in Africa. Common Sci Council, Techn Publ Ser 226: 12-36.

VAN StRAaten P. 2002. Rocks for crops: Agrominerals of Sub-Saharan Africa. ICRAF, Nairobi, Kenya, $338 \mathrm{p}$.

VAn StraAten P And Chesworth W. 1985. Low cost fertilisers: Local geological resources for subsistence farmers in Eastern Africa. In: UNITED NATIONS ECONOMIC COMMISSION FOR AFRICA. Sec. Regional Conference on the Development and Utilisation of Mineral Resources in Africa. Lusaka, Zambia, p. 4-9.

VAN STRAaten P AND FERnANDEs TRC. 1995. Agrogeology in Eastern and Southern Africa: a survey with particular reference to developments in phosphate utilization in Zimbabwe. In: BLENKINSOP TG AND TROMP PL (Eds), Sub-Saharan Economic Geology. Geol Soc Zimbabwe Spec Publ 3, Balkema Publishers, Netherlands, p. 103-118.

VAN StraAten P AND PRIDE C. 1993. Agrogeological resources for small-scale mining. In: PRIDE C AND VAn StraAten P (Eds), Agrogeology and smallscale mining. Small Mining International Bull 5-6: $5-9$.

Von Fragstein P, Pertl W and Vogtmann H. 1988. Verwitterungsverhalten silikatischer Gesteinsmehle unter Laborbedingungen. Zeitschrift für Pflanzenernährung und Bodenkunde 151: 141-146.

VON WILPERT K AND LUKES M. 2003. Ecochemical effects of phonolite rock powder, dolomite and potassium sulphate in a spruce stand on an acidified glacial loam. Nutr Cycl Agroecosyst 65: 115-127.

WeErasuriya TJ, PUshPaKumara S AND COORAY PI. 1993. Acidulated pegmatitic mica: A promising new multi-nutrient mineral fertilizer. Fert Res 34: 67-77. 